Research Article

\title{
Antibiotics Resistance Pattern of Coliform Bacteria Isolated from Slaughterhouse Wastewater in Jega Town, Kebbi State, Nigeria
}

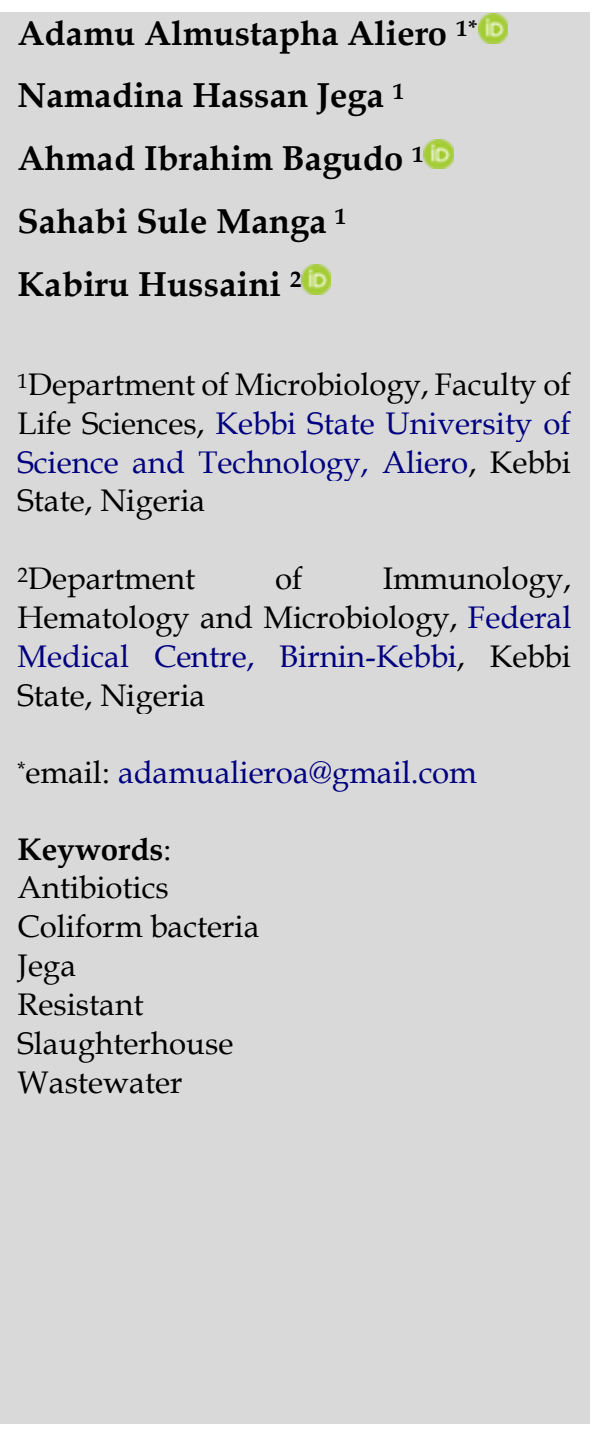

\begin{abstract}
Wastewater is an essential reservoir of pathogenic bacteria, which include resistant strains. This study determined the antibiotics resistance pattern of Coliform bacteria isolated from slaughterhouse wastewater in Juga local government. Five different samples of wastewater from different locations of a slaughterhouse were collected using standard sample collection techniques. Coliform bacteria were isolated using the standard microbiological method. The total bacterial count was determined using plate count agar. Suspected coliforms were identified based on morphological and biochemical tests. Antimicrobial susceptibility testing was carried out using the standard disc diffusion method. The highest bacterial count $\left(8.4 \times 10^{2}\right.$ $\mathrm{CFU} / \mathrm{ml}$ ) was observed from the wastewater collection point, and the lowest bacterial $\left(1.2 \times 10^{2} \mathrm{CFU} / \mathrm{ml}\right)$ count from the slaughtering point. Three Gram-negative bacteria, Escherichia coli, Pseudomonas aeruginosa, and Enterobacter aerogenes, were identified. Escherichia coli was the most frequently isolated in slaughterhouse wastewater 39 $(45.8 \%)$. Among the antibiotics tested against isolated bacteria, Septrin was the most resistant antibiotics recorded against E. coli and $E$. aerogenes with $84.61 \%$ and $88.89 \%$ resistant, respectively. Pseudomonas aeruginosa was found to show higher resistance to Chloramphenicol and Septrin with $84.21 \%$ resistance each. The occurrence of antibioticresistant bacteria from slaughterhouse wastewater showed the risks associated with antimicrobial drug resistance transferred from foodproducing animals to humans. Management concerns, such as local government health officers and community development officers, should increase the sensitization of slaughterhouse workers by organizing conferences or conducting radio talk to educates these slaughterhouse workers on the treatment of slaughterhouse wastewater and health risk associated with antimicrobial-drug resistance transferred from animals to humans.
\end{abstract}

Received: July $12^{\text {th }}, 2020$

Accepted: August 27th, 2020

Published: August 31st, 2020

(C) 2020 Adamu Almustapha Aliero, Namadina Hassan Jega, Ahmad Ibrahim Bagudo, Sahabi Sule Manga, Kabiru Hussaini. Published by Institute for Research and Community Services Universitas Muhammadiyah Palangkaraya. This is an Open Access article under the CC-BY-SA License (http://creativecommons.org/licenses/by-sa/4.0/). DOI: https://doi.org/10.33084/ bjop.v3i3.1530

\section{INTRODUCTION}

The wastewater is an essential reservoir of bacterial pathogens, including resistant isolates (Egesi et al., 2019). Wastewater from the slaughterhouse, if not carefully treated or disposed of, can be good sources of antibiotics resistant bacteria (Manyi-Loh et al., 2018), mainly where slaughterhouse is located near the vegetable farms or community sources of drinking water (Egesi et al., 2019). Activities of meat processing from slaughterhouses in Nigeria are mostly handled by people who are unaware of the slaughterhouse and environmental safety policies (Johnson \& Etokidem, 2019), especially regarding possible microbial contaminations during meat processing (Egesi et al., 2019). Wastewater from 
slaughterhouse may contain a higher level of nutrients such as manure, blood, fats, grease, hair, grit, undigested feeds, salts, phosphates, and nitrates support the growth of microbes, including bacterial pathogens (Kundu et al., 2013; Egesi et al., 2019). Bacteria pathogens from animal sources, especially coliform, acquire by a human was reported to be more challenging to treat (Hiroi et al., 2012). The reason is that current technology in animal food production involved antimicrobial agents in enhancing the production (Hiroi et al., 2012; Egwuenu et al., 2018). The most commonly isolated bacteria from slaughterhouse wastewater are Salmonella spp., Escherichia coli O157 : H7, Shigella spp., Staphylococcus aureus, Streptococcus spp., Yersinia enterocolitica, and Campylobacter spp. (Nafarnda et al., 2012). Similarly, Adebowale et al. (2016) reported the occurrence of Enterobacter aerogenes, Hafnia alvei, Erwinia mallotivora, Edwardsiella ictaluri, Enterobacter amnigenus, E. coli $\mathrm{O} 157$ strains, Proteus mirabilis, Staphylococcus spp., Pseudomonas aeruginosa, Enterobacter intermedius, Yersinia aleksiciae, Serratia odorifera, and Enterobacter cloacae from the central slaughterhouse and its receiving surface water in Abeokuta, Nigeria. Ogbomida et al. (2016) also reported Escherichia sp., Pseudomonas sp., Enterobacter sp., Klebsiella sp., Staphylococcus sp., Salmonella sp., and Streptococcus sp. from slaughterhouse wastewater. Literature has shown that some of these bacterial species were recently classified as ESKAPE (Enterococcus faecium, Staphylococcus aureus, Klebsiella pneumoniae, Acinetobacter baumannii, Pseudomonas aeruginosa, and Enterobacter spp.) bacterial pathogens (Santajit \& Indrawattana, 2016; World Health Organization, 2017; Shrivastava et al., 2018; Savin et al., 2020).

In Nigeria, monitoring environmental sanitation and waste management were established and implemented (Egwuenu et al., 2018). However, the agency lacks monitoring to assure the proper practice of these policies by some local community, which leads to the spread of these commonly resistant bacteria within the community. Research on resistant bacteria is fundamental as this will provide some preliminary information about the existence of these bacteria within the local community (Aslam et al., 2018). However, literature has shown a lack of comprehensive data regarding resistance to antimicrobial agents, especially in African continents, including Nigeria (Egwuenu et al., 2018). Therefore, this study was designed to determine the antibiotics resistance pattern of coliform bacteria isolated from slaughterhouse wastewater.

\section{MATERIALS AND METHODS}

\section{Research sites}

This study was carried out in the Jega local government area of Kebbi State (Figure 1). The local government is located at the latitude and longitude $12.3667^{\circ} \mathrm{N} 4.6333^{\circ} \mathrm{E}$. The inhabitants are predominantly Hausa people by the tribe. The primary occupation of the people is farming and trading. The local government has an area of $891 \mathrm{~km}^{2}$ and a population of 193,352 at the 2006 census. Jega local government has a local market that traditionally holds on Friday, but business activities continue even after the market. The market had an animal's sell point, including a processing meat point where neighboring local governments buy and sell animals and meats, especially during market day. The market serves as sources of meats for many neighboring local government areasthe people of Jega local government slaughterhouse butchering cattle, goats, sheep, and camel.

\section{Sample collection}

A total of five samples were collected from different slaughterhouse sampling points. Samples were collected using the grab sampling method with a wide-mouthed $250 \mathrm{~mL}$ sterilized Pyrex glass bottles with tight screw dustproof stoppers. Slaughterhouse wastewater samples 
were placed in a cooler box and transported to the microbiology laboratory at the Department of Microbiology, Faculty of Life Sciences, Kebbi State University of Science and Technology, Aliero for further analysis.

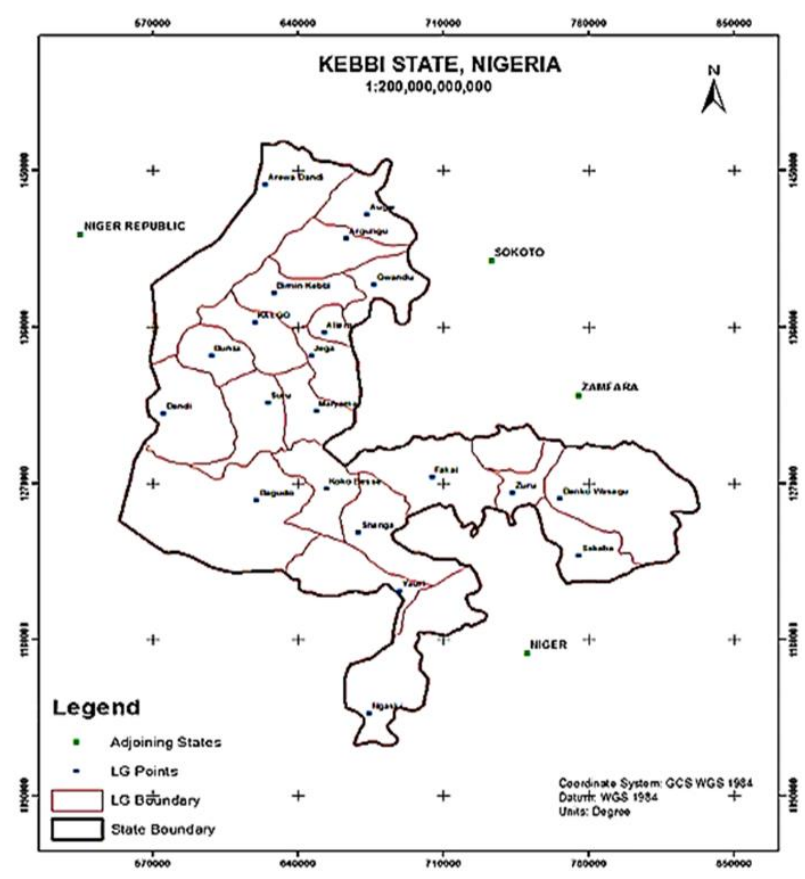

Figure 1. Map of Kebbi State Nigeria, showing the research sites (Ajibola et al., 2018)

\section{Isolation and identification of coliform bacteria}

Coliform bacteria were isolated using the surface spread plate method described by Cheesbrough (2006) and Bashir et al. (2018). Total coliforms and bacterial counts of the collected wastewater samples were determined using Eosin Methylene Blue (EMB) agar and Plate count agar. Serial dilutions of the water samples were made aseptically by transferring $1 \mathrm{~mL}$ of the wastewater sample into $9 \mathrm{~mL}$ of sterile distilled water and diluting that range from $10^{-1}$ to $10^{-6}$. After that, an aliquot of $0.1 \mathrm{~mL}$ from $10^{2}$ dilutions was plated on Plate count agar (Himedia) in duplicates then spread aseptically using a sterile spreader (Egesi et al., 2019). Plates were incubated at $37^{\circ} \mathrm{C}$ for 24 hours and colonies were counted and expressed as colonies forming units per milliliter (CFU/mL).
Coliform counts of wastewater samples were determined using the three-tube analysis of Most Probable Number (MPN) techniques, as described earlier by Cheesbrough (2006) and Bashir et al. (2018) using sterile MacConkey broth. The first set of three tubes had sterile $10 \mathrm{~mL}$ double-strength lactose broth, whereas the second and third sets had $10 \mathrm{~mL}$ single strength broth. All tubes contained Durham tubes before sterilization. The three sets of tubes received $1 \mathrm{~mL}, 0.1 \mathrm{~mL}$, and $0.01 \mathrm{~mL}$ quantities of wastewater samples. The experiment was conducted in duplicates. Tubes were then incubated at $37^{\circ} \mathrm{C}$ for $24-48$ hours to estimate total coliforms and, after that, were examined for acid and gas production. Acid production was detected by the color change of the lactose broth from reddish.

A loopful of samples from positive tubes were inoculated onto Petri plates containing Eosin Methylene blue (EMB) agar using the streaking method, and then plates were incubated at $37^{\circ} \mathrm{C}$ for $24-28$ hours. This selective and differential agar medium inhibits Gram-positive bacteria but allows the growth of Gram-negative coliforms. Coliforms produced large pinkish colonies, with dark centers and green metallic shine. This confirmative test was carried out to determine if the coliforms were of the fecal origin or not. The presence of typical colonies at $37^{\circ} \mathrm{C}$ confirmed coliforms, as referenced by Cheesbrough (2006) and Bashir et al. (2018).

The suspected coliform isolates were further confirmed using convention biochemical tests such as the citrate test, indole test, Urease test, Methyl red test, Voges Proskauer test, Triple sugar iron test. All identification processes were carried out with the guidance from Bergey's Manual of Determinative Bacteriology (Holt et al., 1994).

\section{Antimicrobial susceptibility test}

Antibiotic susceptibility patterns of the pure colony of $E$. coli, $P$. aeruginosa, and E. aerogenes isolates were determined using the disc diffusion method. The 
antibiotic discs used in this study were Ciprofloxacin (10 $\mu \mathrm{g})$, Gentamycin $(10 \mu \mathrm{g})$, Augmentin $(30 \mu \mathrm{g})$, Pefloxacin (20 $\mu \mathrm{g})$, Amoxicillin (10 $\mu \mathrm{g})$, Streptomycin $(30 \mu \mathrm{g})$, Sparfloxacin $(10 \mu \mathrm{g})$, Ofloxacin $(30 \mu \mathrm{g})$, Septrin $(30 \mu \mathrm{g})$, and Chloramphenicol (30 $\mu \mathrm{g})$. Inoculums suspension of a test organism (E. coli, P. aeruginosa, and E. aerogenes) was prepared by inoculating pure colonies into sterile test tubes containing $2 \mathrm{~mL}$ of normal saline. The suspension was then adjusted by standardizing the turbidity to that of 0.5 McFarland standards. The standardized suspension was inoculated on the sterile plates containing freshly prepared Mueller Hinton agar using a sterile cotton swab. The surfaces of the plates were then impregnated with the antibiotic discs using a sterile Forceps. The plates were incubated for 24 hours at $37^{\circ} \mathrm{C}$. After incubation, the inhibition zones were measured in $\mathrm{mm}$ using a ruler by the Clinical and Laboratory Standards Institute (2019).

\section{RESULTS AND DISCUSSION}

A study on antimicrobial-resistant is critical now a day mainly from the African continent, where comprehensive data to show the magnitude of resistance are lacking (Egwuenu et al., 2018). Literature has shown that wastewater from slaughterhouse can be served as a source or reservoir of resistant bacterial pathogens spread within the community if not well treated or disposed of (Egesi et al., 2019). This resistance varies from different locality due to some factors such as the educational background of animal rearers, use of antibiotics in animal feedstuffs, among others (Egwuenu et al., 2018). This hinders the effort to control antimicrobial-resistant humans because resistant bacteria of animal origin are more dangerous than human origin (Hiroi et al., 2012). This research determined the antibiotics resistance pattern of coliform bacteria isolated from slaughterhouse wastewater in Jega local government area Kebbi State, Nigeria.

Out of five samples of wastewater collected from different slaughterhouse points, the result showed that the wastewater collection point had the highest bacterial coliform counts with a mean and standard deviation of $\left(8.73 \pm 0.35 \times 10^{2} \mathrm{CFU} / \mathrm{mL}\right)$ while the Slaughtering point had the lowest coliform bacterial counts with mean and standard deviation of $\left(1.27 \pm 0.31 \times 10^{2} \mathrm{CFU} / \mathrm{mL}\right)$ as presented in Table I. This was in line with the study of Jega et al. (2018), who reported coliform bacteria from slaughterhouse Effluent-Impacted Tagangu River, Aliero, Kebbi State, North-Western Nigeria. The bacterial coliform count reported in this study was similar to the findings of Atuanya et al. (2018) who reported mean and standard deviation of bacterial coliform count ranged $2.7 \times 10^{5} \pm 0.1$ to $3.8 \times 10^{5} \pm 1.4 \mathrm{CFU} / \mathrm{mL}$ and $5.5 \times 10^{5} \pm 0.3$ to $9.2 \times 10^{5} \pm 0.4 \mathrm{CFU} / \mathrm{mL}$ from government and private slaughterhouse from Effluents around Ikpoba River in Benin City, Nigeria. However, Egesi et al. (2019) also reported bacterial coliform from different slaughterhouse points.

Table I. The mean and standard coliform bacterial count of different slaughterhouse wastewater sample in Jega government area, Kebbi States, Nigeria

\begin{tabular}{lcc}
\hline \multicolumn{1}{c}{$\begin{array}{c}\text { Slaughterhouse } \\
\text { points }\end{array}$} & $\begin{array}{c}\text { Mean } \pm \text { SD coliform } \\
\text { counts }\left(\mathbf{x 1 0 ^ { 2 }} \text { CFU/mL) }\right.\end{array}$ & p-value \\
\hline Wastewater collection & $8.73 \pm 0.35$ & \\
point & & \\
Washing point & $1.77 \pm 0.46$ & 0.03671 \\
Drainage & $1.87 \pm 0.44$ & \\
Slaughtering point & $1.27 \pm 0.31$ & \\
Un-skinning point & $1.3 \pm 0.2$ & \\
\hline CFU: Colony-forming unit & &
\end{tabular}

This research's findings showed higher coliform count from the wastewater collection point compares to either point of the slaughterhouse. The comparison between the different slaughterhouse points using Tukey's multiple comparisons showed statistically different $(p=$ 0.03671). This finding is similar to Egesi et al. (2019), who reported higher coliform bacterial counts from 
slaughterhouse effluents than slaughterhouse sampling points.

The suspected coliform bacteria were identified using a standard biochemical test, as shown in Table II. Among the coliform bacteria isolated from the different slaughterhouse sampling points, E. coli is the most abundant bacteria isolated with 39 points $(45.8 \%)$, as presented in Table III. The presence of E. coli from slaughterhouse wastewater is an indication of fecal contamination, and therefore such water needs to be given special treatment to arrest the spread of this pathogenic organism within the environment. Disease caused by $E$. coli of animal origin is more difficult to treat, especially the resistant isolate due to the frequent use of antibiotics in animal feeds (Hiroi et al., 2012). This is in line with the finding of Jega et al. (2018) who reported the $E$. coli as the most abundant bacteria isolated from slaughterhouse effluent-impacted Tagangu River, Aliero, Kebbi State, North-Western Nigeria. Similarly, Egesi et al. (2019) reported E. coli as the second most abundant coliform bacteria isolated from slaughterhouse effluents discharged into water bodies in Owerri, Nigeria. However, Tesfaye et al. (2019) reported E. coli as the most abundant coliform bacteria from wastewater samples from health facilities, slaughterhouses, downstream rivers, and a wastewater treatment plant in Addis Ababa, Ethiopia.

Other Gram-negative bacteria isolated from slaughterhouse wastewater are $P$. aeruginosa and E. aerogenes. The presence of $P$. aeruginosa in slaughterhouse wastewater was also reported by previous studies (Igbinosa et al., 2012; de Oliveira et al., 2013; Ayogu et al., 2018). This confirmed the statement by Yayan etal. (2015) that $P$. aeruginosa is currently one of the dangerous nosocomial organisms that can be transmitted in many ways, including food products such as meat. The percentage (22.4\%) of P. aeruginosa reported in this study is lower than the $37.6 \%$ reported by Rabiu and Falodun (2017) from wastewater of a slaughterhouse in Ibadan, Nigeria.

Table II. Biochemical characteristics of coliform bacteria isolated from slaughterhouse waste-water in Jega local government area, Kebbi States Nigeria

\begin{tabular}{|c|c|c|c|c|}
\hline \multirow{2}{*}{\multicolumn{2}{|c|}{ Parameters }} & \multicolumn{3}{|c|}{ Strains results } \\
\hline & & 1 & 2 & 3 \\
\hline \multicolumn{2}{|c|}{ Gram's staining } & - (rod) & - (rod) & - (rod) \\
\hline \multicolumn{2}{|c|}{ Citrate } & + & - & + \\
\hline \multicolumn{2}{|l|}{ Motility } & + & + & - \\
\hline \multicolumn{2}{|l|}{ Oxidase } & - & + & + \\
\hline \multicolumn{2}{|l|}{ Catalase } & + & + & + \\
\hline \multicolumn{2}{|l|}{ Indole } & - & + & - \\
\hline \multicolumn{2}{|l|}{ Urease } & - & - & - \\
\hline \multicolumn{2}{|c|}{ Methyl red } & + & + & - \\
\hline \multicolumn{2}{|c|}{ Vogues Proskauer } & + & - & - \\
\hline \multirow{3}{*}{$\begin{array}{l}\text { Triple sugar } \\
\text { iron }\end{array}$} & Slant & Alkaline & Acid & Alkaline \\
\hline & But & Acid & Acid & Acid \\
\hline & $\mathrm{H}_{2} \mathrm{~S}$ & - & - & - \\
\hline \multicolumn{2}{|l|}{ Starch } & - & + & - \\
\hline \multicolumn{2}{|l|}{ Gelatin } & + & - & + \\
\hline \multirow{5}{*}{$\begin{array}{l}\text { Sugar } \\
\text { fermentation }\end{array}$} & Glucose & $+/$ Acid & $+/$ Acid & - \\
\hline & Maltose & $+/$ Acid & $+/$ Acid & - \\
\hline & Sucrose & $+/$ Acid & $+/$ Acid & - \\
\hline & Lactose & - & $+/$ Acid & - \\
\hline & Mannitol & + / Acid & $+/$ Acid & $+/$ Acid \\
\hline \multicolumn{2}{|c|}{ Possible microorganism } & E. aerogenes & E.coli & $\begin{array}{c}P . \\
\text { aeruginosa }\end{array}$ \\
\hline
\end{tabular}

Table III. Coliform bacteria isolated from wastewater samples from different slaughterhouse points in Jega local government area, Kebbi States Nigeria

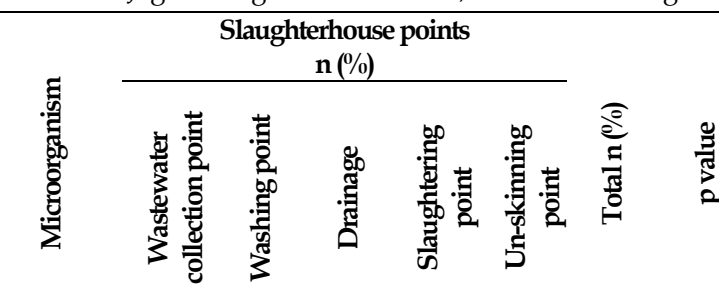

\begin{tabular}{|c|c|c|c|c|c|c|c|}
\hline E.coli & $\begin{array}{c}18 \\
(46.2)\end{array}$ & $\begin{array}{c}8 \\
(20.5)\end{array}$ & $\begin{array}{c}1 \\
(2.6)\end{array}$ & $\begin{array}{c}5 \\
(12.8)\end{array}$ & $\begin{array}{c}7 \\
(17.9)\end{array}$ & $\begin{array}{c}39 \\
(45.8)\end{array}$ & \multirow{4}{*}{0.5057} \\
\hline $\begin{array}{l}\text { E. } \\
\text { aerogenes }\end{array}$ & $\begin{array}{c}14 \\
(51.9)\end{array}$ & $\begin{array}{c}2 \\
(7.4)\end{array}$ & $\begin{array}{c}5 \\
(18.5)\end{array}$ & $\begin{array}{c}6 \\
(22.2)\end{array}$ & $\begin{array}{c}0 \\
(0)\end{array}$ & $\begin{array}{c}27 \\
(31.8)\end{array}$ & \\
\hline $\begin{array}{l}P . \\
\text { aeruginosa }\end{array}$ & $\begin{array}{c}10 \\
(52.6)\end{array}$ & $\begin{array}{c}0 \\
(0)\end{array}$ & $\begin{array}{c}3 \\
(15.8)\end{array}$ & $\begin{array}{c}1 \\
(5.3)\end{array}$ & $\begin{array}{c}5 \\
(26.3)\end{array}$ & $\begin{array}{c}19 \\
(22.4)\end{array}$ & \\
\hline Total & $\begin{array}{c}42 \\
(49.4)\end{array}$ & $\begin{array}{c}10 \\
(11.8)\end{array}$ & $\begin{array}{c}9 \\
(10.6)\end{array}$ & $\begin{array}{c}12 \\
(14.1)\end{array}$ & $\begin{array}{c}12 \\
(14.1)\end{array}$ & $\begin{array}{c}85 \\
(100)\end{array}$ & \\
\hline
\end{tabular}

The result of antibiotics resistant pattern of the coliform bacteria isolated (Figure 2) indicates that $E$. coli showed higher resistance to Septrin and Augmentin among the antibiotics tested with $(84.61 \%)$ and $(89.74 \%)$ resistant, respectively. The higher resistance of $E$. coli recorded in this research is worrying as recent literature showed that many of the antimicrobial-resistant strains of $E$. coli that 
cause human urinary tract and bloodstream infections appear to have arisen from contaminated meat products (Egwuenu et al., 2018). The finding of this research is in line with the report of Atuanya et al. (2018) and Savin et al. (2020), who reported the resistance of $E$. coli isolated from slaughterhouse Effluents to Septrin and Augmentin. Similarly, Jega et al. (2018) also reported the resistance of
E. coli isolated from slaughterhouse Effluent-Impacted Tagangu River, Aliero, to Augmentin. However, Tesfaye et al. (2019) reported the resistant $E$. coli isolated from e in wastewater samples from health facilities, slaughterhouse, downstream rivers, and a wastewater treatment plant in Addis Ababa, Ethiopia to Septrin including multi-drugs resistant isolate.

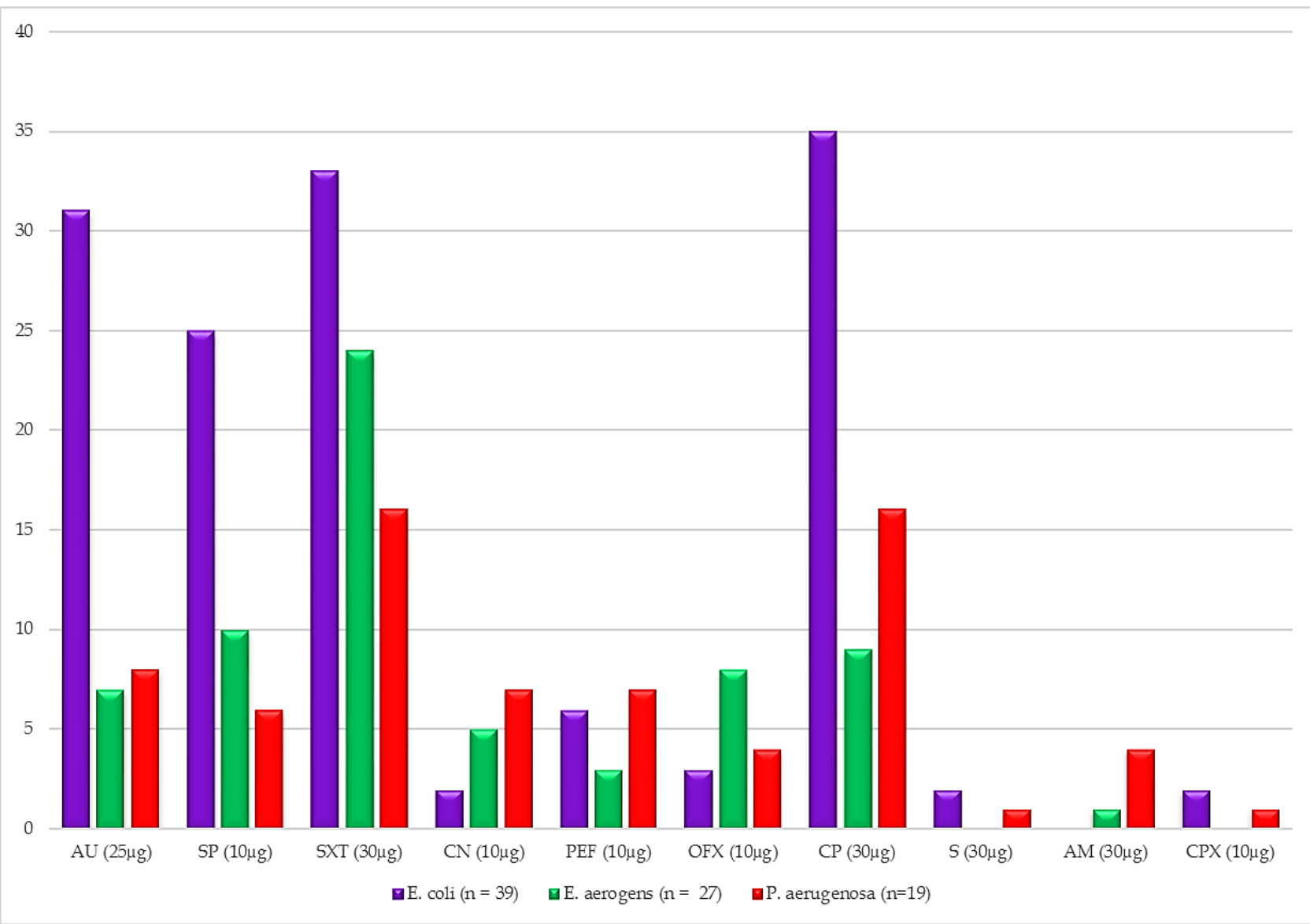

Figure 2. Antibiotics resistant pattern of coliform bacteria isolated from wastewater slaughterhouse in Jega local government area, Kebbi States Nigeria. AU = Augmentin, SP = Sparfloxacin, SXT= Septrin, CN: Gentamycin, PEF: Pefloxacin, OFX = Ofloxacin, CP: Chloramphenicol, $\mathbf{S}=$ Streptomycin, $\mathbf{A M}=$ Amoxicillin, $\mathbf{C P X}$ : Ciprofloxacin

Enterobacter aerogenes showed resistance to Septrin $(88.89 \%)$. Enterobacter aerogenes were reported to be an opportunistic nosocomial pathogen and are sought out to be one of the many critical causes for extra-intestinal infections next to $E$. coli. The infection associated with this organism is respiratory and urinary tract infections, specifically cystitis, and wound, bloodstream, and central nervous system infections (Flores-Mireles et al., 2015). The finding of this research is in line with the report of Jega et al. (2018), who also reported the resistance of Enterobacter spp. isolated from slaughterhouse Effluent-Impacted Tagangu River, Aliero to Augmentin and Septrin.

The results of this finding showed that $P$. aeruginosa is highly resistant to Chloramphenicol and Septrin with $84.21 \%$ resistant each. These results are in line with Rabiu and Falodun's (2017) finding, who reported 40.6\% resistance of $P$. aeruginosa isolated from wastewater of a slaughterhouse in Ibadan, Nigeria, to Chloramphenicol. 
This bacterium's resistance to this drug is alarming as this bacterium was reported to be one of the dangerous nosocomial microorganisms that can be transmitted in many ways, including food products such as meat (Yayan et al., 2015). Infection caused by P. aeruginosa, exceptionally resistant isolates seems challenging to treat due to its resistance to a variety of antibiotics, and patients can die from pneumonia caused by Pseudomonas spp. (Tran et al., 2014). The increasing resistance of $P$. aeruginosa to numerous antibiotics results from excessive antibiotic administration in both humans and animals, leading to the accumulation of antibiotic resistance and crossresistance between antibiotics and the appearance of multidrug-resistant (MDR) forms of $P$. aeruginosa. This study's finding is in line with Atuanya et al. (2018), who reported resistant $P$. aeruginosa isolated from slaughterhouse Effluents around Ikpoba River in Benin City, Nigeria. This is contrary to the findings of Jega et al. (2018), who reported the sensitivity of P. Aeruginosa isolated from slaughterhouse Effluent-Impacted Tagangu River, Aliero to both Chloramphenicol and Septrin.

\section{CONCLUSION}

The occurrence of antimicrobial-resistant pathogens such as E. coli, E. aerogenes, and P. aeruginosa from this slaughterhouse points showed the risks associated with antimicrobial drug resistance transferred from foodproducing animals to humans. It is recommended that the management concern, such as local government health officers, and community development officers should increase on the sensitization of slaughterhouse workers by organizing conferences or conducting radio talk to educates these slaughterhouse workers on the treatment of slaughterhouse wastewater and health risk associated with antimicrobial drug resistance transferred from food-producing animals to humans.

\section{ACKNOWLEDGMENT}

The author thanks all staff of the Microbiology laboratory of Kebbi State University of Science and Technology, Aliero, for their kind support during this study.

\section{REFERENCES}

Adebowale, O.O., Adedamola, J., Olanike, A., \& Eniola, K. (2016). Potential Bacterial Zoonotic Pathogens Isolated from a Major Abattoir and its Receiving Surface Water in Abeokuta, Nigeria. Alexandria Journal of Veterinary Sciences, 50(1), 94-98. doi:10.5455/ajvs.222912

Ajibola, O., Omoleke, S.A., \& Omisakin, O.A. (2018). Current status of cerebrospinal meningitis and impact of the 2015 meningococcal C vaccination in Kebbi, Northwest Nigeria. Vaccine, 36(11), 1423-1428. doi:10.1016/j.vaccine.2018.01.084

Aslam, B., Wang, W., Arshad, M.I., Khurshid, M., Muzammil, S., Rasool, M.H., Nisar, M.A., Alvi, R.F., Aslam, M.A., Qamar, M.U., Salamat, M.K.F., \& Baloch, Z. (2018). Antibiotic resistance: a rundown of a global crisis. Infection and Drug Resistance, 11, 1645-1658. doi:10.2147/IDR.S173867

Atuanya, E.I., Nwogu, N.A., \& Orah, C.U. (2018). Antibiotic Resistance and Plasmid Profiles of Bacteria Isolated from Abattoir Effluents around Ikpoba River in Benin City, Nigeria. Journal of Applied Sciences and Environmental Management, 22(11), 1749-1755. doi:10.4314/jasem.v22i11.7

Ayogu, T.E., Orji, J.O., Nwojiji, E.C., Umezurike, R.C., \& Ibiam, U.U. (2018). Antibiotic Susceptibility Pattern of Salmonella and Pseudomonas Species Isolated from Meat Market and Ogoja Road Abattoir Effluents in Abakaliki Metropolis. World Journal of Medical Sciences, 15(1), 34-47. doi:10.5829/idosi.wjms.2018.34.47

Bashir, I., Adam, A.S., Yahaya, H.S., Makeri, D., Ntulume, I., Aliero, A.A., \& Afolabi, R.O. (2018). Assessment of bacteriological quality of borehole water in Wamakko local government, Sokoto state, Nigeria. Novel Research in Microbiology Journal, 2(6), 175-184. doi:10.21608/NRMJ.2018.22710 
Cheesbrough, M. (2006). District Laboratory Practice in Tropical Countries. 2nd Edition. Part 2. London, UK: Cambridge University Press. p.425.

Clinical and Laboratory Standards Institute. 2019. Performance standards for antimicrobial susceptibility testing. $2^{\text {th }}$ edition. CLSI Supplement M100. Wayne, Pennsylvania, US: Clinical and Laboratory Standards Institute. p.26.

Egesi, C.O., Ezebuiro, V., Ekeleme, A.C., \& Obiukwu, C.E. (2019). Compliance Monitoring of Microbiological and Physicochemical Parameters of Abattoirs' Effluents Discharged into Water Bodies in Owerri, Nigeria. Microbiology Research Journal International, 28(6), 1-16. doi:10.9734/mrji/2019/v28i630147

Egwuenu, A., Obasanya, J., Okeke, I., Aboderin, O., Olayinka, A., Kwange, D., Ogunniyi, A., Mbadiwe, E., Omoniyei, L., Omotayo, H., Niyang, M., Abba, F., Kudla, F., TWG, A., \& Ihekweazu, C. (2018). Antimicrobial use and resistance in Nigeria: situation analysis and recommendations, 2017. Pan African Medical Journal - Conference Proceedings, 8(8), 2. doi:10.11604/pamj.cp.2018.8.2.701

Flores-Mireles, A.L., Walker, J.N., Caparon, M., \& Hultgren, S.J. (2015). Urinary tract infections: epidemiology, mechanisms of infection and treatment options. Nature Reviews Microbiology, 13(5), 269-284. doi:10.1038/nrmicro3432

Hiroi, M., Kawamori, F., Harada, T., Sano, Y., Miwa, N., Sugiyama, K., Hara-Kudo, Y., \& Masuda, T. (2012). Antibiotic resistance in bacterial pathogens from retail raw meats and foodproducing animals in Japan. Journal of Food Protection, 75(10), 1774-1782. doi:10.4315/0362028x.jfp-11-479

Holt, J.G., Krieg, N.R., Sneath, P.H.A., Stanley, J.T., \& William, S.T. (1994) Bergey's Manual of Determinative Bacteriology. Baltimore, US: Lippincott Williams \& Wilkins. p.566.

Igbinosa, E.O., Odjadjare, E.E., Igbinosa, I.H., Orhue, P.O., Omoigberale, M.N.O., \& Amhanre, N.I. (2012). Antibiotic Synergy Interaction against Multidrug-Resistant Pseudomonas aeruginosa Isolated from an Abattoir Effluent Environment. The Scientific World Journal, 2012, 308034. doi:10.1100/2012/308034
Jega, B.G., Adebisi, O.O., \& Manga, S.S. (2018). Antibiotic Susceptibility of Bacteria Isolated from Abattoir Effluent-Impacted Tagangu River, Aliero, Kebbi State, North-Western Nigeria. South Asian Journal of Research in Microbiology, 2(4), 1-8. doi:10.9734/sajrm/2018/v2i430072

Johnson, O.E. \& Etokidem, A.J. (2019). Occupational Hazards and Health Problems among Butchers in Uyo, Nigeria. Nigerian Medical Journal, 60(3), 106-112. doi:10.4103/nmj.NMJ_57_19

Kundu, P., Debsarkar, A., \& Mukherjee, S. (2013). Treatment of Slaughter House Wastewater in a Sequencing Batch Reactor: Performance Evaluation and Biodegradation Kinetics. BioMed Research International, 2013, 134872. doi:10.1155/2013/134872

Manyi-Loh, C., Mamphweli, S., Meyer, E., \& Okoh, A. (2018). Antibiotic Use in Agriculture and Its Consequential Resistance in Environmental Sources: Potential Public Health Implications. Molecules, 23(4), 795. doi:10.3390/molecules23040795

Nafarnda, W.D., Ajayi, I.E., Shawulu, J.C., Kawe, M.S., Omeiza, G.K., Sani, N.A., Tenuche, O.Z., Dantong, D.D., \& Tags, S.Z. (2012). Bacteriological Quality of Abattoir Effluents Discharged into Water Bodies in Abuja, Nigeria. International Scholarly Research Notices, 2012, 515689. doi:10.5402/2012/515689

Ogbomida, E.T., Kubeyinje, B., \& Ezemonye, L.I. (2016). Evaluation of bacterial profile and biodegradation potential of abattoir wastewater. African Journal of Environmental Science and Technology, 10(2), 50-57. doi:10.5897/AJEST2015.1945

de Oliveira, K.M.P., Júlio, P.D.S., \& Grisolia, A.B. (2013). Antimicrobial susceptibility profile of Pseudomonas spp. isolated from a swine slaughterhouse in Dourados, Mato Grosso do Sul State, Brazil. Revista Argentina de Microbiología, 45(1), 57-60.

Rabiu, A.G. \& Falodun, O.I. (2017). Multi-drug Resistant Pseudomonas Species Isolated from the Wastewater of an Abattoir in Ibadan, Nigeria. Journal of Applied Life Sciences International, 13(1), 1-9. doi:10.9734/JALSI/2017/34522 
Santajit, S. \& Indrawattana, N. (2016). Mechanisms of Antimicrobial Resistance in ESKAPE Pathogens. BioMed Research International, 2016, 2475067. doi:10.1155/2016/2475067

Savin, M., Bierbaum, G., Hammerl, J.A. Heinemann, C., Parcina, M., Sib, E., Voigt, A., \& Kreyenschmidt, J. (2020). Antibiotic-resistant bacteria and antimicrobial residues in wastewater and process water from German pig slaughterhouses and their receiving municipal wastewater treatment plants. Science of The Total Environment, 727, 138788. doi:10.1016/j.scitotenv.2020.138788

Shrivastava, S.R., Shrivastava, P.S., \& Ramasamy, J. (2018). World health organization releases global priority list of antibiotic-resistant bacteria to guide research, discovery, and development of new antibiotics. Journal of Medical Society, 32(1), 76-77. doi:10.4103/jms.jms_25_17

Tesfaye, H., Alemayehu, H., Desta, A.F., \& Eguale, T. (2019). Antimicrobial susceptibility profile of selected Enterobacteriaceae in wastewater samples from health facilities, abattoir, downstream rivers and a WWTP in Addis Ababa, Ethiopia. Antimicrobial Resistance and Infection Control, 8(1), 134. doi:10.1186/s13756019-0588-1

Tran, C.S., Rangel, S.M., Almbad, H., Kierbel, A., Givskov, M., Tolker-Nielsen, T., Hauser, A.R., \& Engel, J.N. (2014). The Pseudomonas aeruginosa type III translocon is required for biofilm formation at the epithelial barrier. PLoS Pathogens, 10(11), e1004479. doi:10.1371/journal.ppat.1004479

World Health Organization. (2017). WHO publishes list of bacteria for which new antibiotics are urgently needed. $\quad$ https://www.who.int/newsroom/detail/27-02-2017-who-publishes-listof-bacteria-for-which-new-antibiotics-areurgently-needed

Yayan, J., Ghebremedhin, B., \& Rasche, K. (2015). Antibiotic Resistance of Pseudomonas aeruginosa in Pneumonia at a Single University Hospital Center in Germany over a 10-Year Period. PLoS One, 10(10), e0139836. doi:10.1371/journal.pone.0139836 